\title{
STUDI DESKRIPTIF KADAR DEBU PADA BAGIAN PRODUKSI PT. MUARA KAYU SENGON DESA KARANGANYAR KECAMATAN JATILAWANG KABUPATEN BANYUMAS TAHUN 2016
}

\author{
Dipta Hastantoro ${ }^{1)}$, Marsum ${ }^{2)}$
}

\begin{abstract}
Abstrak
Studi deskriptif kadar debu pada bagian produksi PT. Muara Kayu Sengon Desa Karanganyar Kecamatan Jatilawang Kabupaten Banyumas Tahun 2016. Pencemaran udara diartikan sebagai adanya bahanbahan atau zat-zat asing di dalam udara yang menyebabkan perubahan sususan (komposisi) udara dari keadaan normalnya seperti debu. PT. Muara Kayu Sengon merupakan penghasil kayu lapis dan berpotensi untuk menimbulkan kontaminasi di udara tempat kerja berupa partikel debu kayu di dalam ruangan saat karyawaan bekerja sehingga mengakibatkan lingkungan menjadi tercemar oleh partikel debu kayu, sehingga kualitas udara menjadi menurun. Penelitian ini bertujuan untuk mengukur kadar debu di ruang produksi PT. Muara Kayu Sengon. Jenis penelitian yang digunakan adalah deskriptif dengan pendekatan crossectional untuk mendapatkan gambaran tentang kadar debu total di ruang produksi PT. Muara Kayu Sengon Banyumas tahun 2016. Pengukuran kadar debu total dilakukan pada 10 titik di ruang produksi PT. Muara Kayu Sengon Banyumas dengan hasil pengukuran rata-rata adalah $20,5824 \mathrm{mg} / \mathrm{m}^{3}$, hasil tertinggi di titik $8(\mathrm{H})$ sebesar $37,632 \mathrm{mg} / \mathrm{m}^{3}$ dan terendah di titik $3(\mathrm{C})$ sebesar $10,08 \mathrm{mg} / \mathrm{m}^{3}$. Standar yang digunakan adalah Permenakertrans No. 13/Men/X/2011 tentang nilai ambang batas faktor fisik dan faktor kimia di tempat kerja adalah $5 \mathrm{mg} / \mathrm{m}^{3}$ dengan kadar tertinggi diperkenankan $10 \mathrm{mg} / \mathrm{m}^{3}$. Ratarata pengukuran suhu $35,2^{\circ} \mathrm{C}$ dengan persyaratan $18-30^{\circ} \mathrm{C}$, kelembaban $75,2 \%$ dengan persyaratan $65-95 \%$, laju ventilasi $0,1 \mathrm{~m} / \mathrm{s}$ dengan persyaratan $0,15-0,25 \mathrm{~m} / \mathrm{s}$ dan arah angin menunjukkan ke arah selatan. Standar yang digunakan adalah Kepmenkes NO. 1405/Menkes/SK/XI/2002 tentang persyaratan kesehatan lingkungan perkantoran dan industri. Berdasarkan hasil tersebut dapat disimpulkan hasil rata-rata kadar debu total di ruang produksi melebihi $N A B$ yaitu $20,5824 \mathrm{mg} / \mathrm{m}^{3}$, suhu melebihi standar yaitu $35,2^{\circ} \mathrm{C}$, laju ventilasi tidak memenuhi standar yaitu $0,1 \mathrm{~m} / \mathrm{s}$. Ruang produksi sebaiknya dilengkapi dengan rekayasa alat untuk mengurangi paparan debu.
\end{abstract}

Kata kunci : Kadar debu,Kayu, PT. Muara Kayu Sengon

\begin{abstract}
Dust levels descriptive study in the production department of plywood mill PT. Muara Kayu Sengon Karanganyar Village Jatilawang Districts Banyumas District 2016. Air pollution is defined as the presence of a foreign substance or subtances in the air that cause changes in the composition (composition) their normal air like dust. PT. Muara Kayu Sengon is a producer of plywood and has the potential to cause contamination in the workplace air in the form particles of wood dust in the room when employees work so that air quality is lowered. This study aims to measure the levels of dust in the production department of PT. Muara Kayu Sengon. Type of study is a descriptive with crossectional approach to get an idea of the total dust levels in the production department of PT. Muara Kayu Sengon. Total dust concertation measurement carried out at 10 points in the production department of PT. Muara Kayu Sengon Banyumas with average measurement results is 20,5824 mg/m the highest results is in the $8(\mathrm{H})$ point with $37,632 \mathrm{mg} / \mathrm{m}^{3}$ and the lowest in the $3(\mathrm{C})$ point with $10,08 \mathrm{mg} / \mathrm{m}^{3}$. Standard used is Permenakertrans No. 13/Men/X/2011 on the threshold values of physical factors and chemical factors in the workplace is $5 \mathrm{mg} / \mathrm{m}^{3}$ with the highest levels of safety $10 \mathrm{mg} / \mathrm{m}^{3}$. Average temperature measurement is $35,2^{\circ} \mathrm{C}$ with requirements is $18-30^{\circ} \mathrm{C}$, humidity is $75,2 \%$ with requirements $65-95 \%$, ventilation rate is $0,1 \mathrm{~m} / \mathrm{s}$ with requirements 0,15-0,25 m/s and the wind direction toward the south. Standard tha used is Kepmenkes NO. 1405/Menkes/SK/XI/2002 about requirements of environmental health office and industrial. Based on these results we can conclude the results oh the average total dust concertation in the production department exceeded threshold values is $20,5824 \mathrm{mg} / \mathrm{m}^{3}$, temperature exceeds the standards that $35,2^{\circ} \mathrm{C}$, the ventilation rate does not meet the standards that $0,1 \mathrm{~m} / \mathrm{s}$. Production department should be equipped with engineering tools to reduce dust exposure.
\end{abstract}

Key words : levels of wood dust, PT. Muara Kayu Sengon

\section{PENDAHULUAN}

Udara merupakan campuran dari gas udara kering yang bebas bahan pencemar. Komposisi normal

1) Email : hastantoro@gmail.com

2) Email : marsumrahma@gmail.com udara terdiri atas gas nitrogen 78\%, oksigen 20,93\%, dan karbon dioksida $0,03 \%$, sementara selebihnya berupa gas argon, neon, krypton, xenon dan helium. 
Udara juga mengandung uap air, debu, bakteri, spora, dan sisa tumbuh-tumbuhan yang mempunyai dampak positif dan negatif bagi makhluk hidup serta lingkungan (H. J. Mukono, 2008, h. 5).

Dampak negatif akibat udara salah satunya adalah pengotoran udara, pengotoran udara sudah lama menjadi masalah kesehatan pada masyarakat salah satunya adalah pencemaran udara. Pencemaran udara diartikan sebagai adanya bahan-bahan atau zat-zat asing di dalam udara yang menyebabkan perubahan sususan (komposisi) udara dari keadaan normalnya (Wisnu Arya Wardana, 1999, h. 27). Akibat dari pencemaran udara tersebut adalah timbulnya berbagai penyakit antara lain kerusakan paru-paru, silicosis, asbestosis, berryliosis, anthracosis, stenosis dan sideorsis.

Debu merupakan partikel benda padat yang terjadi karena proses mekanis (pemecahan atau reduksi) terhadap masa padat, di mana ia masih dipengaruhi oleh gravitasi (Dr. AL. Slamet Ryadi Skm, 1982, h. 52). Kadar debu total yang diizinkan terdapat di udara dan tidak mengganggu kenikmatan kerja menurut Permenaker tentang nilai ambang batas faktor fisik dan faktor kimia di tempat kerja No. 13 tahun 2011 adalah jika Kadar debu total $\leq 5 \mathrm{mg} / \mathrm{m}^{3}$. Pada beberapa kondisi, didapati bahwa Kadar debu total di tempat kerja ternyata masih melebihi NAB, hal yang sama seperti penelitian yang dilakukan oleh Taufik Nurohim (2014, h. 40) menunjukan hasil dimana nilai Kadar debu total masih melebihi ambang batas yaitu 59,62 $\mathrm{mg} / \mathrm{m}^{3}$. Selain itu pada penelitian yang dilakukan oleh Bayu Aji Februar (2015, h. 60) menunjukan hasil nilai Kadar debu total yaitu $17,78 \mathrm{mg} / \mathrm{m}^{3}$.

PT. Muara Kayu Sengon merupakan penghasil kayu lapis yang berdiri pada tanggal 27 Oktober 2014 dan berlokasi di Jalan Raya Margasana No. 1 Desa Karanganyar Kecamatan Jatilawang, Kabupaten Banyumas, Propinsi Jawa Tengah. Pabrik yang dimiliki Bapak Torik Alamudi ini mempunyai jumlah pekerja sebanyak 375 pekerja, kapasitas produksi kurang lebih 1600 lembar/hari dengan luas lahan $50.000 \mathrm{~m}^{2}$. PT. Muara Kayu Sengon berpotensi untuk menimbulkan kontaminasi di udara tempat kerja berupa partikel debu kayu di dalam ruangan saat karyawaan bekerja sehingga mengakibatkan lingkungan menjadi tercemar oleh partikel debu kayu, sehingga kualitas udara menjadi menurun.

Hasil pemeriksaan kapasitas paru-paru yang dilakukan Balai Hiperkes dan Keselamatan Kerja di Sulawesi Selatan pada tahun 1999 terhadap 200 pekerja di 8 perusahaan. Diperoleh 45\% responden mengalami penyempitan paru-paru, $1 \%$ mengalami penyumbatan paru-paru, $1 \%$ responden mengalami penyempitan dan penyumbatan paru-paru (http://www.scribd.com/doc/130358543/asthmaKerja-Akibat-Debu-Kayu).

Dampak negatif pengolahan kayu lapis adalah pencemaran udara yang timbul akibat proses pengolahan. Hal ini dapat dilihat secara organoleptik pada daun di sekitar pabrik yang terdapat debu, selain itu PT. Muara Kayu Sengon belum pernah dilakukan penelitian tentang kualitas udara.Berdasarkan uraian di atas, maka peneliti ingin mengadakan penelitian dengan judul "Studi Deskriptif Kadar debu total pada Bagian Produksi Pabrik Kayu Lapis PT. Muara Kayu Sengon Desa Karanganyar Kecamatan Jatilawang Kabupaten Banyumas Tahun 2016”.

Tujuan Penelitian adalah untuk mengetahui kadar debu pada bagian Produksi PT. Muara Kayu Sengon Tahun 2016.

Manfaat penelitian ini adalah Tempat kerja mendapat gambaran tentang potensi bahaya dan faktor bahaya yang ada di tempat kerja dan lingkungan kerja serta dapat mengupayakan pengendalian potensi bahaya dan faktor bahaya tempat kerja dan lingkungan kerja.

\section{METODE PENELITIAN}

Metode penelitian yang digunakan adalah penelitian deskriptif yaitu suatu metode penelitian yang dilakukan dengan tujuan untuk melihat gambaran tentang paparan kadar debu di PT. Muara Kayu Sengon Desa Karanganyar Kecamatan Jatilawang Kabupaten Banyumas Tahun 2016 dengan menggunakan pendekatan crossectional.

PT. Muara Kayu Sengon yang berlokasi di Jalan Margasana Desa Karanganyar Kecamatan Jatilawang Kabupaten Banyumas.

Subyek penelitian ini adalah Kadar debu total pada ruang produksi PT. Muara Kayu Sengon yang meliputi pengukuran suhu, pengukuran kelembaban, pengukuran laju ventilasi dan arah angin, kadar debu total dan wawancara terhadap pekerja di ruang produksi pada sift pagi dan malam.

\section{III.HASIL DAN PEMBAHASAN}

Hasil rata-rata pengukuran kadar debu total yang dilakukan selama 1 hari pada tanggal 13 Juni 2016 pada pukul 13.00 WIB-14.40 WIB, di Ruang Produksi PT. Muara Kayu Sengon didapatkan hasil $20,5824 \mathrm{mg} / \mathrm{m}^{3}$. Kadar debu total tersebut melebihi standar yang ditetapkan oleh Permenaker No. 13/Men/X/2011 tentang nilai ambang batas faktor fisik dan faktor kimia di tempat kerja kandungan debu maksimal di dalam udara ruangan dalam pengukuran debu rata-rata 8 jam adalah $5 \mathrm{mg} / \mathrm{m}^{3}$ dengan kadar tertinggi diperkenankan $10 \mathrm{mg} / \mathrm{m}^{3}$.

Kadar debu total paling banyak berada pada titik 8 (H) sebanyak 37,632 $\mathrm{mg} / \mathrm{m}^{3}$, hal ini disebabkan karena titik tersebut berada di mesin pemotong kayu awal (Jumping Cross Cut), titik tersebut juga berada jauh dari bagian tembok yang terbuka. Kadar debu total paling sedikit berada pada titik 3 (C), sebanyak $10,8 \mathrm{mg} / \mathrm{m}^{3}$, hal ini dipengaruhi karena pada titik tersebut berdekatan dengan tembok yang terbuka dan berada pada mesin Cross Cut Tekan dan Cross Cut Tarik yang sedikit menghasilkan debu

Berdasarkan hasil pengukuran suhu pada Ruang Produksi PT. Muara Kayu Sengon diketahui bahwa 
suhu di 10 titik bagian produksi mempunyai range $30^{\circ} \mathrm{C}-37^{\circ} \mathrm{C}$ sehingga rata-rata diperoleh $35,2^{\circ} \mathrm{C}$. Suhu tersebut melebihi standar yang ditetapkan oleh Kepmenkes NO.1405/Menkes/SK/XI/2002 Tentang Persyaratan Kesehatan Lingkungan Kerja Perkantoran dan Industri yaitu untuk suhu udara di dalam ruangan industri yaitu $18-30^{\circ} \mathrm{C}$. Suhu tertinggi berada pada titik $3(\mathrm{C})$, titik $8(\mathrm{H})$ dan titik 9 (I) dengan suhu $37^{\circ} \mathrm{C}$, hal ini dipengaruhi karena ke 3 titik tersebut berada dekat dengan winjer joint dan Conveyor, kedua mesin tersebut merupakan mesin yang menggunakan motor penggerak.

Suhu terendah berada pada titik $10(\mathrm{~J})$ dengan suhu $30^{\circ} \mathrm{C}$, hal ini dipengaruhi karena titik tersebut berada dekat dengan tembok yang terbuka. Suhu juga dapat dipengaruhi oleh banyaknya mesin yang selalu beroperasi selama 8 jam dalam 1 shift. Suhu yang tinggi dapat mengakibatkan ruangan menjadi kering dan sedikit mengandung uap air sehingga tidak mengikat banyak polutan berupa debu. Polutan tersebut akan melayang-layang lebih lama di udara, sehingga konsentrasi pencemaran semakin tinggi.

Menurut H.J Mukono(1997) suhu udara yang menurun dapat menyebabkan kelembaban udara relative, sehingga akan meningkatkan laju ventilasi reaksi suatu bahan kimia.

Hasil rata-rata laju ventilasi di bagian Produksi PT. Muara Kayu Sengon rata-rata adalah $0,1 \mathrm{~m} / \mathrm{s}$ dengan arah angin menunjukkan ke arah selatan.Laju ventilasi tersebut tidak memenuhi standar yang ditetapkan oleh Kepmenkes No. 1405/Menkes/SK/XI/2002 Tentang Persyaratan Kesehatan Lingkungan Kerja Perkantoran dan Industri untuk laju ventilasi di dalam industri yaitu $0,15-0,25 \mathrm{~m} / \mathrm{s}$.

Keadaan tersebut dapat dipengaruhi oleh keadaan ruangan yang belum sepenuhnya tertutup sehingga udara dari luar ruangan masuk ke ruang produksi, laju ventilasi ini akan mempengaruhi Kadar debu total di bagian produksi tersebut Angin akan membawa debu berterbangan di udara lebih lama. Laju ventilasi akan menyebabkan penyebaran debu yang tidak terfokus di titik tertentu, sehingga menyebabkan perbedaan di setiap titik.

Hasil rata-rata kelembaban udara di Ruang Produksi PT. Muara Kayu Sengon pada saat dilakukan pengukuran Kadar debu total totaladalah 75,2\%. Kelembaban tersebut masih memenuhi standar yang ditetapkan oleh Kepmenkes No. 1405/Menkes/SK/XI/2002 Tentang Persyaratan Kesehatan Lingkungan Kerja Perkantoran Dan Industri untuk kelembaban di dalam industri yaitu 6595\%. Kelembaban tertinggi berada pada titik 2 (B) dan titik 4 (D) dengan kelembaban 83\%, sedangkan kelembaban paling rendah berada pada titik 9 (I) dengan kelembaban 58\%. Tingkat kelembaban yang rendah mengakibatkan sedikitnya uap air sehingga tidak mengikat banyak polutan berupa debu. Polutan tersebut akan melayang-layang lebih lama di udara, sehingga konsentrasi pencemaran semakin tinggi. Menurut H.J Mukono(1997).

\section{IV.KESIMPULAN DAN SARAN}

Hasil rata-rata pengukuran Kadar debu total yang dilakukan pada Ruang Produksi PT. Muara Kayu Sengon didapatkan hasil 20,5824 mg/m³ . Kadar debu total tersebut melebihi standar yang ditetapkan oleh Permenaker No. 13/Men/X/2011 tentang nilai ambang batas faktor fisik dan faktor kimia di tempat kerja kandungan debu maksimal di dalam udara ruangan dalam pengukuran debu rata-rata 8 jam adalah $5 \mathrm{mg} / \mathrm{m}^{3}$ dengan kadar tertinggi diperkenankan $10 \mathrm{mg} / \mathrm{m}^{3}$. Kadar debu total paling banyak berada pada titik 8 (H) sebanyak 37,632 $\mathrm{mg} / \mathrm{m}^{3}$. Kadar debu total paling sedikit berada pada titik 3 (C), sebanyak 10,8 $\mathrm{mg} / \mathrm{m}^{3}$.

Berdasarkan hasil pengukuran suhu pada Ruang Produksi PT. Muara Kayu Sengon rata-rata diperoleh suhu $35,2^{\circ} \mathrm{C}$. Suhu tersebut melebihi standar yang ditetapkan oleh Kepmenkes NO.1405/Menkes/SK/XI/2002 Tentang Persyaratan Kesehatan Lingkungan Kerja Perkantoran Dan Industri yaitu untuk suhu udara di dalam ruangan industri yaitu $18-30^{\circ} \mathrm{C}$. Suhu tertinggi berada pada titik 3 (C), titik $8(\mathrm{H})$ dan titik 9 (I) dengan suhu $37^{\circ} \mathrm{C}$.

Hasil rata-rata arah angin dan laju ventilasi di bagian Produksi PT. Muara Kayu Sengon rata-rata adalah $0,1 \mathrm{~m} / \mathrm{s}$ dengan arah angin menunjukkan ke arah selatan.Laju ventilasi tersebut tidak memenuhi standar yang ditetapkan oleh Kepmenkes NO. 1405/Menkes/SK/XI/2002 Tentang Persyaratan Kesehatan Lingkungan Kerja Perkantoran Dan Industri untuk laju ventilasi di dalam industri yaitu $0,15-0,25 \mathrm{~m} / \mathrm{s}$.

Hasil rata-rata kelembaban udara di Ruang Produksi PT. Muara Kayu Sengon adalah 75,2\%. Standar yang ditetapkan oleh Kepmenkes No. 1405/Menkes/SK/XI/2002 Tentang Persyaratan Kesehatan Lingkungan Kerja Perkantoran dan Industri untuk kelembaban di dalam industri yaitu 6595\%. Kelembaban tertinggi berada pada titik 2 (B) dan titik 4 (D) dengan kelembaban 83\%, sedangkan kelembaban paling rendah berada pada titik 9 (I) dengan kelembaban 58\%.

Pada ruang produksi sebaiknya di lengkapi dengan rekayasa alat berupa Scrubbing untuk mengurangi paparan debu.

Pihak pabrik sebaiknya memasang Exhauster untuk mengeluarkan debu dari dalam ruang produksi ke luar ruang produksi sehingga debu di dalam ruang produksi dapat berkurang.Penggunaan filter untuk menangkap polutan partikel pada permukaan filter dan bersifat semipermeable sehingga dapat dibersihkan.Perawatan saluran penyedot debu pada setiap mesin (Dukting).

\section{DAFTAR PUSTAKA}


Depkes RI, 2004, Modul Pelatihan Bagi Fasilitator Kesehatan Kerja

Februar Aji Bayu, 2015, Hubungan Paparan Debu Dengan Kapasitas Paru Tenaga Kerja Di Pabrik Kayu PT. Kemilau Anugerah Sejati Desa Pageraji Kecamatan Cilongok Kabupaten Banyumas Tahun 2015

Fengel Districh \& Gerd Wegener, 1995, Кауи : Kimia, Ultrastuktur, Reaksi-reaksi

Hidayat ALimul Aziz, 2007, Metode Penelitian Kebidanan Teknik Ananalisis Data

Mukono, HJ, 2008, Pencemaran Udara Dan Gangguan Saluran Pernapasan, Surabaya

Nurohim, Taufik, 2014, Studi Deskriptif Kadar debu total totalPada Bagian Produksi Pabrik Kayu
UD. Kartika Sari Di Desa Prigi Kecamatan Sigaluh Kabupaten Banjarnegara Tahun 2014

Permenaker No 13/MEN/X/2011 tentang Nilai Ambang Batas Faktor Fisik Dan Kimia Di Tempat Kerja

Riyadi, Slamet, 1982, tentang Pencemaran Udara

Rosmawati, Azizah, 2013, Studi Deskriptif Kualitas Udara di Tempat Pembakaran Batu Kapur di Desa Karangdawa Kecamatan Cilongok Kabupaten Banyumas Tahun 2015

Sastrawijaya, Tresna, 1991, tentang Pencemaran Lingkungan

Wardhana Arya Wisnu, 2004, tentang Dampak Pencemaran Lingkungan 